Article

\title{
Broadcasting Winter Wheat Can Increase Grain Yield without Reducing the Kernels per Spike and the Kernel Weight
}

\author{
Yunlong Zhai ${ }^{1,2,+}$, Quanzhong $\mathrm{Wu}^{1,+}{ }^{\dagger}$, Guodong Chen ${ }^{1}$, Hailin Zhang ${ }^{2} \oplus$, Xiaogang Yin $^{2}$ and \\ Fu Chen ${ }^{2, *}$ \\ 1 College of Plant Sciences, Tarim University, Xinjiang 843300, China; zylzky@cau.edu.cn (Y.Z.); \\ qzhwu@126.com (Q.W.); cgdzky@163.com (G.C.) \\ 2 College of Agronomy and Biotechnology, China Agricultural University, Haidian District, Beijing 100193, \\ China; hailin@cau.edu.cn (H.Z.); xiaogangyin@cau.edu.cn (X.Y.) \\ * Correspondence: chenfu@cau.edu.cn; Tel.: +86-106-273-3376 \\ + The author contributed equally to this paper.
}

Received: 15 November 2018; Accepted: 12 December 2018; Published: 19 December 2018

\begin{abstract}
In North China, row spacing is the most common planting pattern used for winter wheat. Currently, there are three sowing and tillage methods for row spacing: rotary tillage sowing with straw return (RTS), subsoil tillage sowing with straw return (DTS), and no-tillage sowing with straw return (NTS). Recently, Hao proposed a new sowing pattern called uniform broadcast sowing with straw return (BSS) which could increase winter wheat yield. In this research, a field experiment was conducted during the growing seasons in 2011-2012 and 2012-2013. The winter wheat (Triticum aestivum L.) variety Jimai 22 was sowed with the four seeding and tillage methods-RTS, DTS, NTS, and BSS - at the China Agriculture University Wuqiao experimental station in the North China Plain. After tillage sowing and determining the sowing efficiency, the effective cover ratio of the seeds was measured, and the emergence ratio was calculated after emergence. In the two growing seasons, the growth and development stages were recorded. The dry matter accumulation (DMA), the yield, and the yield components (spikes per hectare, kernels per spike, and kernel weight) were also determined. We also measured the canopy structure leaf area index (LAI) and the stand uniformity. The results showed that BSS had the lowest emergence rate and lowest plant stands when compared with the other treatments. However, BSS had the highest grain yield at $7599.0 \mathrm{~kg} \cdot \mathrm{ha}^{-1}$ and $9763.3 \mathrm{~kg} \cdot \mathrm{ha}^{-1}$, which was $11.55,16.17,20.16 \%$ and $13.01,15.68,21.88 \%$ higher than DTS, RTS, and NTS in the 2011/2012 and 2012/2013 growing seasons, respectively. The improved grain yield of BSS was due to the increased productive tillers per hectometer-squared, which was attributed to the higher stand uniformity. More importantly, the increased tillers per hectare and grain yield were not accompanied by a reduction in grain number per spike or grain weight. The stand uniformity could facilitate canopy construction and population architecture and result in more even sunlight distribution, increased leaf area index (LAI) and sunlight interception, and enhanced photosynthetic activity. The stand uniformity also could increase both the pre-anthesis and post-anthesis DMA and promote the harvest index (HI). This study indicates that BSS is the most suitable sowing method for winter wheat production in North China.
\end{abstract}

Keywords: winter wheat; broadcast sowing; stand uniformity; grain yield; yield components

\section{Introduction}

The North China Plain (NCP) is one of the most important granaries in China, producing $41 \%$ of domestic wheat (Triticum aestivum L.) grains annually [1,2]. Water shortage in the NCP, due to 
the overexploitation of groundwater with the rapid development of irrigated farming, has been a bottleneck for the sustainable development of agriculture. As one of the water-saving strategies to solve this problem, conservation tillage, including no-tillage sowing with straw covering, has been considered to retain soil moisture via improvement of soil physical properties (e.g., soil aeration, soil porosity, and soil permeability) [3,4]. However, continuous no-tillage as a long-term strategy has been shown to increase the bulk density, reduce the arable layer, and expand the plow pan, which impedes root development and decreases winter wheat yield [5]. Some contradictory results have been observed related to the effect of no-till farming on grain yield. For example, in rain-fed areas and irrigated areas with low productivity, no-till farming has been shown to increase winter wheat grain yield [6] and total yields in a rice-wheat rotation system in both rain-fed and irrigated areas [3]. On the other hand, in irrigated areas with a high yield potential, yield responses to no-tillage farming are inconsistent: some scholars found that no-tillage farming increased grain yield, whereas others argued that no-tillage farming decreased grain yield due to the reduced number of spikes per unit area, grains per spike, and the 1000-grain weight of wheat $[7,8]$.

Subsoiling can efficiently loosen the deep soil, facilitate soil infiltration, and conserve soil water. In the NCP, subsoiling has been proven to alleviate soil compaction, increase crop production, and improve water use efficiency [6,8]. However, the popularity of subsoiling is limited in China due to the high energy demand, large economic cost, and low working efficiency.

Planting patterns, including bed planting, straw mulching, furrow planting, and wide-narrow row spacing, can significantly affect grain yield [9]. Numerous studies have indicated that narrow row spacing could increase wheat grain yield [10]. Xue et al. [11] reported that reducing row spacing or improving seedling uniformity within the rows decreased plant-to-plant variability and ultimately increased grain yield. In recent years, a new planting pattern known as "wide-precision" has been broadly adopted in the NCP, and this strategy may increase the spikes per unit area without decreasing grains per spike and the 1000-grain weight $[9,12]$.

Previous studies have indicated that high stand uniformity was favorable to high yield production [13]. A nonuniform plant pattern reduces the plant yield, while the uniform spatial distribution of plants can increase wheat yield through improved planting geometry, which can better utilize the land and environment resources [14]; improve germination, yield uniformity, and quality; and increase weed suppression. However, until now, there have been no reports that address both uniform and random sowing patterns for grain production [15].

Here, we report a new winter wheat sowing method in which the seeds are sown in a completely random distribution in the field. We hypothesized that, as mentioned above, the random spread of winter wheat seeds in a more uniform distribution pattern in the field (compared with strip sowing) would result in greater stand uniformity and higher grain yield.

The present study, therefore, compared uniform broadcast sowing (BSS) with three conventional winter wheat sowing methods: rotary tillage sowing with straw return (RTS), no-tillage sowing with straw return (NTS), and subsoil tillage sowing with straw return (DTS). To investigate the hypothesis, we determined the effect of the uniform distribution pattern on (I) emergence rate; (II) dry matter accumulation; (III) tiller number; (IV) grain yield and yield components; and (V) stand uniformity. The results of the analysis could provide a theoretical and technical basis for the implementation of the mechanical broadcasting of winter wheat in the NCP.

\section{Materials and Methods}

\subsection{The Experimental Site}

The field experiment was carried out during the 2011-2012 and 2012-2013 growing seasons at the China Agriculture University Wuqiao experimental station $\left(37^{\circ} 37^{\prime} 22^{\prime \prime} \mathrm{N}, 116^{\circ} 25^{\prime} 54^{\prime \prime} \mathrm{E}, 19.7 \mathrm{~m}\right.$ a.s.l.) in Hebei Province of China. This region is classified as a temperate continental monsoon climate. The annual mean precipitation is $675.7 \mathrm{~mm}$, the mean temperature is $12.7^{\circ} \mathrm{C}$, the accumulative 
temperature above $0{ }^{\circ} \mathrm{C}$ is $4832.4^{\circ} \mathrm{C}$, and the sunshine duration is $2623.3 \mathrm{~h}$. The average temperature was $9.3^{\circ} \mathrm{C}$ and $8.6^{\circ} \mathrm{C}$, and the precipitation was $142.9 \mathrm{~mm}$ and $134 \mathrm{~mm}$ for the 2011-2012 and 2012-2013 growing seasons respectively.

The soil type is alluvial damp soil (about 130-170 cm), the soil texture is silt loam at the top 0-20 cm soil layer ( $58 \%$ silt, $14.5 \%$ clay, and $27.5 \%$ sand). The average soil organic matter (SOM) content is $12.4 \mathrm{~g} \cdot \mathrm{kg}^{-1}$; the total $\mathrm{N}$, the available $\mathrm{P}$, and the available $\mathrm{K}$ are $0.79 \mathrm{~g} \cdot \mathrm{kg}^{-1}, 44.6 \mathrm{mg} \cdot \mathrm{kg}^{-1}$, and $94.2 \mathrm{mg} \cdot \mathrm{kg}^{-1}$, respectively. The groundwater table is detected at $6-9 \mathrm{~m}$.

\subsection{The Experimental Design}

The field experiment consists of four treatments, namely, rotary tillage sowing with straw return (RTS), subsoil tillage sowing with straw return (DTS), no-tillage sowing with straw return (NTS), and broadcast sowing with straw return (BSS). The plot area for each treatment was 0.3 ha. The detailed description of what each treatment entails is given below.

RTS: Returning the chopped maize straw to the field, spreading the base fertilizer, rotary cultivating two times (working depth was about $14 \mathrm{~cm}$ ), drill seeder sowing with a row spacing of $15 \mathrm{~cm}$.

DTS: Returning the chopped maize straw to the field, spreading the base fertilizer, subsoiling once with 1SQ-340 subsoiler (working depth was about $40-50 \mathrm{~cm}$ ), rotary cultivating one time, drill seeder sowing with a row spacing of $15 \mathrm{~cm}$.

NTS: Returning the chopped maize straw to the field, multifunction direct seeder sowing to complete the base fertilizer application, rotary cultivation of a sowing row of $10 \mathrm{~cm}$ with a depth of $15 \mathrm{~cm}$, sowing and compacting at the same time with a micro-furrow-ridge seedbed (the furrow-ridge difference was about $12 \mathrm{~cm}$, the seeds were sown in the furrow with a wide-narrow row planting pattern, and the row spacing was a 10 and $20 \mathrm{~cm}$ alternative arrangement); no more than $33 \%$ of the land was rotary tilled, so it is a kind of no-tillage method.

BSS: Returning the chopped maize straw to the field, the no-ridge combined seeder sowing (HSTV Model, Hengshui Jinfeng Farm Machinery Co. Ltd. Hebei Province China) to complete the fertilizer application, sowing and compacting at one time; the seeds were broadcast and uniformly dispersed in the soil without ridges and furrows.

The winter wheat cultivar Jimai 22 was chosen as the material because of the excellent performance. It is a semi-winter, semi-creeping, and early-maturing cultivar with high tiller rate. The leaves are small and erect, and the plant height is about $75 \mathrm{~cm}$. Jimai 22 has been the most planted winter wheat cultivar for 6 consecutive years from 2010 to 2015 in China (Farmers daily, August 17, 2015, in Chinese). Jimai 22 was sowed on October 11 and October 10 in 2011 and 2012, respectively, and harvested on June 11 for both growing seasons in a winter wheat/summer maize double-cropping system. The seeding rate was $270 \mathrm{~kg} \cdot \mathrm{ha}^{-1}$ for NTS, $240 \mathrm{~kg} \cdot \mathrm{ha}^{-1}$ for DTS and RTS, and $300 \mathrm{~kg} \cdot \mathrm{ha}^{-1}$ for BSS in the first growing season, and $277.5 \mathrm{~kg} \cdot \mathrm{ha}^{-1}$ for NTS, $265.2 \mathrm{~kg} \cdot \mathrm{ha}^{-1}$ for DTS and RTS, and $307.5 \mathrm{~kg} \cdot \mathrm{ha}^{-1}$ for BSS in the second growing season. In the second growing season, the soil in the DTS, RTS, and BSS treatments was compacted after sowing because of low soil water content. Basal fertilizers at rates of $450 \mathrm{~kg} \mathrm{~N} \mathrm{ha}^{-1}$ as urea and $300 \mathrm{~kg} \mathrm{P}_{2} \mathrm{O}_{5} \mathrm{ha}^{-1}$ as diammonium phosphate were applied before soil preparation. Nitrogen, at rates of $150 \mathrm{~kg} \cdot \mathrm{ha}^{-1}$ and $75 \mathrm{~kg} \cdot \mathrm{ha}{ }^{-1}$ as urea, was applied at the jointing and anthesis stages, respectively, with $70 \mathrm{~mm}$ of irrigation water.

\subsection{Measurements}

In both growing seasons, the tillage and sowing efficiency were calculated according to Zhai [16]. Soil water content in the topsoil $(0-10 \mathrm{~cm})$ was measured using the oven-drying method. The soil cores were oven-dried at $105^{\circ} \mathrm{C}$ to a constant weight. The emergence number was determined from four randomly selected areas of $1 \mathrm{~m}^{2}$ for each plot. Also, the emergence ratio was calculated according to the seeding rate. We also measured the sowing depth and the number of uncovered seeds to calculate the seeds' effective cover ratio. 
In the two growing seasons, the growth stages of wheat were recorded when $75 \%$ of the plants entered specific stages, including emergence, wintering, revival, jointing, booting date, filling, and maturity.

Before wintering, three $30 \mathrm{~cm}$ lines for RTS, DTS and NTS and three areas of $21.2 \times 21.2 \mathrm{~cm}$ for BSS were randomly selected to measure the subcrown internodes and tillering node depth.

Areas of $1 \mathrm{~m}^{2}$ from four different locations within each experimental unit were randomly selected, and the total number of tillers were counted and averaged every 10 days. The productive tillers were recorded at the grain filling period. The productive tiller ratio was defined as follows:

$$
\begin{aligned}
\text { Productive tiller ratio }(\%) & =\text { spikes per unit area at maturity period/tillers per unit } \\
& \text { area at jointing period } \times 100
\end{aligned}
$$

\subsubsection{The Leaf Area Index (LAI)}

After emergence, the LAI was determined every 10 days, and the sampling stopped during the wintering period. For RTS, DTS, and NTS, three lines with a length of $30 \mathrm{~cm}$ were randomly selected from each plot and, for BSS, three $21.2 \times 21.2 \mathrm{~cm}$ areas randomly selected in each plot: within these selected areas, the leaf areas were measured with a Yaxin-1241 leaf area tester.

\subsubsection{The Mean Leaf Inclination Angle (MLIA)}

The MLIA was measured using a CI-110 digital canopy structure analyzer in the morning and afternoon at the jointing, heading, and filling stages.

\subsubsection{Plant Height Component Index (PHCI)}

The PHCI was measured at the grain filling stage from 30 randomly selected plants from each plot. The internode length was measured, and the PHCI was calculated according to Wei [17].

$$
\mathrm{I}_{\mathrm{L}}=\frac{\mathrm{L}_{1}+\mathrm{L}_{2}}{\mathrm{~L}} \quad \mathrm{I}_{\mathrm{n}}=\frac{\mathrm{L}_{\mathrm{n}}}{\mathrm{L}_{\mathrm{n}}+\mathrm{L}_{\mathrm{n}+1}}
$$

In Equation (2), $\mathrm{L}$ is the internode length, and $\mathrm{n}$ is the internode order from the spike, which is marked with 1.

\subsubsection{Dry Matter Accumulation (DMA)}

After emergence, the DMA was determined every 10 days during both growing seasons, and sampling stopped during the wintering period. For RTS, DTS, and NTS, three lines with a length of $30 \mathrm{~cm}$ were randomly selected from each plot and, for BSS, three $21.2 \times 21.2 \mathrm{~cm}$ areas randomly selected in each plot; from the selected areas, the plants were cut and all the organs from a harvested sample were separated in different bags. All of the samples were oven-dried for $30 \mathrm{~min}$ at $105{ }^{\circ} \mathrm{C}$ to quickly cease plant metabolic activity, followed by oven-drying at $70{ }^{\circ} \mathrm{C}$ until obtaining a constant weight to attain the total aboveground biomass $\left(\mathrm{kg} \cdot \mathrm{ha}^{-1}\right)$.

\subsubsection{Yield and Yield Components}

When the winter wheat reached maturity, $4 \mathrm{~m}^{2}$ areas were selected at random in each experimental plot to determine the grain yield. The air-dried seed weight was adjusted to $13 \%$ moisture per plot and then converted to weights per hectare to calculate grain yield $\left(\mathrm{kg} \cdot \mathrm{ha}^{-1}\right)$. A total of $4000 \mathrm{kernels}$ were randomly sampled to measure the 1000-kernel weight, and 30 plants (randomly selected) were harvested to count the kernel number per spike. 


\subsubsection{Stand Uniformity}

The stand uniformity was estimated using the stand deviation of 20 continuously selected plant heights with three replicates. The function is as follows:

$$
\text { Stand uniformity }=1 / \mathrm{S}=1 / \sqrt{\frac{\sum(\mathrm{x}-\overline{\mathrm{x}})^{2}}{\mathrm{n}}}
$$

In Equation (3), the $S$ is the stand deviation; $\mathrm{x}$ is the plant height, the plant grain number per spike, the spike length, and the grains per spike; $\bar{x}$ is the average plant height; and $n$ is the plant number.

\subsection{Statistical Analysis}

The effect of the treatments was analyzed using ANOVA $(\alpha=0.05)$ with Statistical Analysis Software (version 19.0, SPSS Inc., Chicago, IL, USA). Multiple comparisons were generated using LSD tests $(\alpha=0.05)$.

\section{Results}

\subsection{Weather Conditions}

For both growing seasons, the temperature patterns appeared to be similar, whereas the growing seasonal rainfall was 142.9 and $134 \mathrm{~mm}$ for 2011/2012 and 2012/2013, respectively. For the 2011/2012 growing season, the rainfall mostly occurred in November $(38.6 \mathrm{~mm}$ ) and April $(60.6 \mathrm{~mm})$, and for the 2012/2013 growing season, the rainfall was no more than $28 \mathrm{~mm}$. The sunshine duration was $1669 \mathrm{~h}$ and $1590.9 \mathrm{~h}$ for the 2011/2012 and 2012/2013 growing seasons, respectively (Figure 1.).

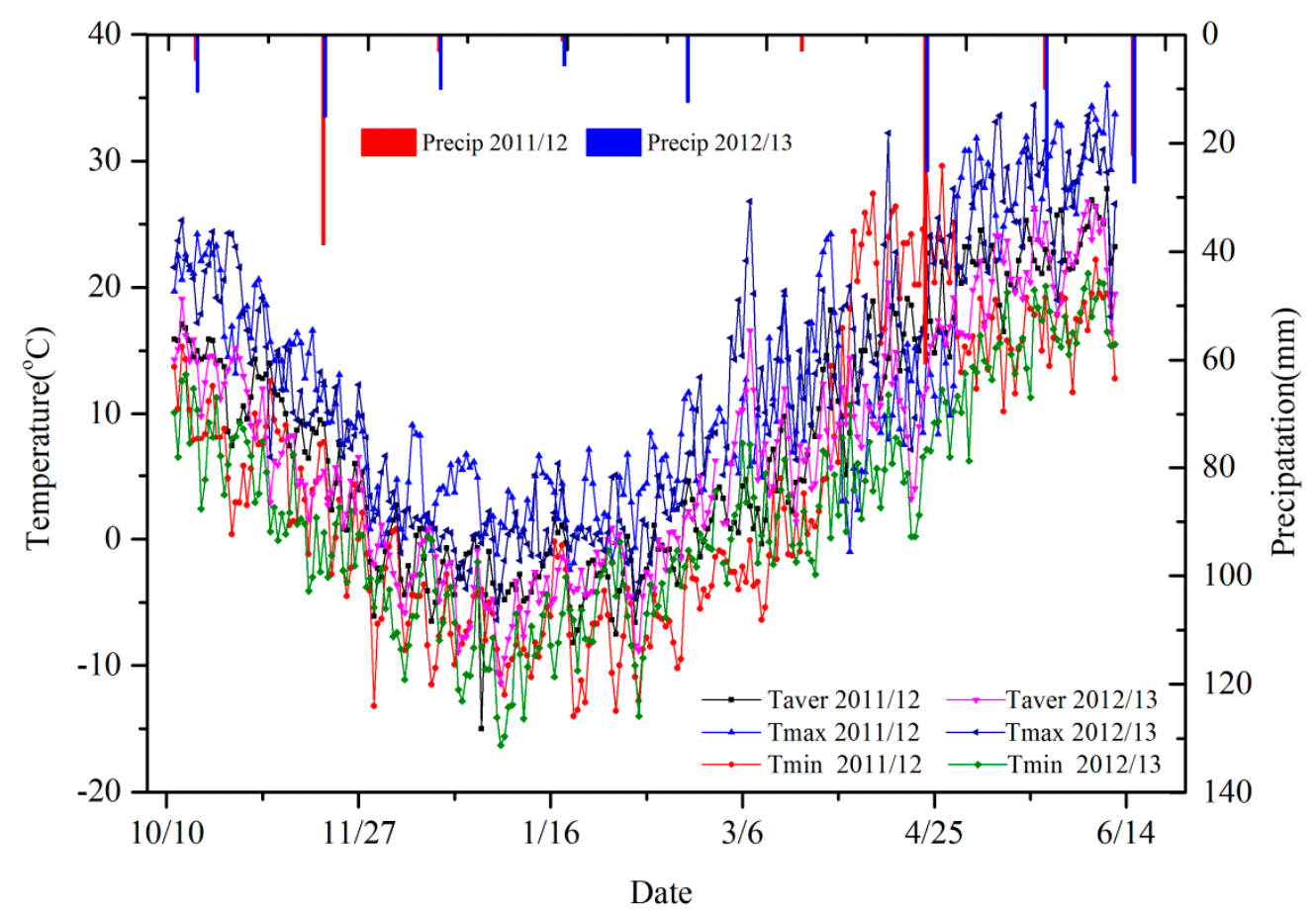

Figure 1. The daily maximum, minimum, and average temperature and monthly precipitation during the growing seasons in 2011/2012 and 2012/2013

\subsection{Emergence and Seedling}

Seed coverage was affected by the tillage and sowing methods (Table 1). Also, the coverage rate of BSS was significantly lower than that of the NTS, DTS, and RTS treatments in both growing seasons. For NTS, the seeds were sown in furrows between two ridges, where the ridges and furrows were 
mechanically formed. The sowing depth for NTS was higher than that for the other treatments, and the seed coverage ratio was the highest.

In the 2012/2013 growing season, RTS, DTS, and BSS were compacted after sowing, and the sowing depth was significantly lower than that of the 2011/2012 season. No significant difference in sowing depth was detected in the 2011/2012 season, and the sowing depth for NTS was significantly lower than that of the others in the 2012/2013 season (Table 1).

Soil water content was closely related to seed emergence. In NTS, after the seeds were sown in the furrows and immediately compacted, the soil was little disturbed. The soil water content in the $0-10 \mathrm{~cm}$ layer of NTS was significantly higher than that of the other treatments. There were no differences between the soil water content of DTS, RTS, and BBS in the two growing seasons. The highest to lowest soil water content for the four treatments was NTS $>$ RTS $>$ DTS $>$ BSS.

Table 1. Effect of different seeding and tillage methods on sowing and seedling emergence quality of winter wheat for the four treatments in the 2011/2012 and 2012/2013 growing seasons.

\begin{tabular}{llccccc}
\hline Year & Treatment & $\begin{array}{c}\text { Tillage and } \\
\text { Seeding Efficiency } \\
\mathbf{( h a}^{-1} \cdot \mathbf{h}^{-\mathbf{1}} \mathbf{)}\end{array}$ & $\begin{array}{c}\text { Sowing } \\
\text { Depth } \\
\mathbf{( \mathbf { c m } )}\end{array}$ & $\begin{array}{c}\text { Effective } \\
\text { Coverage } \\
\text { Ratio } \mathbf{( \% )}\end{array}$ & $\begin{array}{c}\text { 0-10 cm Depth } \\
\text { Soil Water } \\
\text { Content } \mathbf{( \% )}\end{array}$ & $\begin{array}{c}\text { Emergence } \\
\text { Rate } \mathbf{( \% )}\end{array}$ \\
\hline \multirow{2}{*}{$2011 / 2012$} & 0.47 & $3.79 \mathrm{aA}$ & $98.98 \mathrm{aA}$ & $28.09 \mathrm{aA}$ & $89.03 \mathrm{aA}$ \\
& NTS & 0.15 & $3.28 \mathrm{aA}$ & $98.89 \mathrm{aA}$ & $22.18 \mathrm{bB}$ & $86.03 \mathrm{bB}$ \\
& DTS & 0.17 & $3.14 \mathrm{aA}$ & $98.90 \mathrm{aA}$ & $22.67 \mathrm{bB}$ & $85.58 \mathrm{bB}$ \\
& RTS & 0.50 & $4.16 \mathrm{aA}$ & $89.92 \mathrm{bB}$ & $20.91 \mathrm{bB}$ & $63.98 \mathrm{cC}$ \\
\hline \multirow{2}{*}{$2012 / 2013$} & BSS & 0.47 & $3.80 \mathrm{aA}$ & $99.01 \mathrm{aA}$ & $25.66 \mathrm{aA}$ & $87.20 \mathrm{aA}$ \\
& NTS & 0.15 & $2.39 \mathrm{bA}$ & $98.88 \mathrm{aA}$ & $19.46 \mathrm{bB}$ & $84.28 \mathrm{bB}$ \\
& DTS & 0.17 & $2.55 \mathrm{bA}$ & $98.85 \mathrm{aA}$ & $19.80 \mathrm{bB}$ & $83.95 \mathrm{bB}$ \\
& RSS & 0.53 & $2.56 \mathrm{bA}$ & $91.42 \mathrm{bB}$ & $19.15 \mathrm{bB}$ & $68.65 \mathrm{cC}$ \\
\hline
\end{tabular}

Note: The lowercase and capital letters indicate significant differences at 0.05 and 0.01 levels in one season, respectively (LSD); this coding applies to other tables with these characters. Abbreviations-BSS: uniform broadcast sowing; RTS: rotary tillage sowing with straw return; DTS: subsoil tillage sowing with straw return; NTS: no-tillage sowing with straw return.

There were great significant differences in the emergence rates among the treatments, with BSS having the lowest. In the second growing season, with seeds dispersed in the $0-10 \mathrm{~cm}$ soil layer, the emergence rate increased due to the soil compaction after sowing and the increased seeding rate. NTS had the highest emergence in both growing seasons because of the higher soil water content, the compaction of soil, and the close contact between the seeds and soil. DTS was higher than RTS in emergence rates. However, no significant difference was detected between these two treatments.

\subsection{Winter Wheat Growth and Development}

Winter wheat's development stages are presented in Table 2. As it is shown, for NTS, with the higher soil water content and well-compacted soil, the seedling emergence was 1 day earlier than DTS and RTS and 2 days earlier than BSS in 2011/2012; emergence was 1 day earlier than DTS and RTS in the 2012/2013 growing season. No effect was observed for the overwintering of the four treatments.

Since the soil was compacted, covering the ridges with straw resulted in a slower increasing soil temperature. With deeper tiller nodes in the soil, NTS developed more slowly than the others after overwintering; for example, NTS was 3 days later than DTS and RTS and 4 days later than BSS in 2011/2012, and it was 2 days later than DTS and RTS and 3 days later than BSS in 2012/2013.

BSS in 2012/2013 was compacted after sowing since, in 2011/2012, the seedling emergence was later than that of the other three treatments. The loose soil of BSS resulted in rapidly increasing soil temperature in the spring, and BSS was earlier to revive compared with the other treatments. 
Table 2. The growth and development stages of winter wheat for the NTS, DTS, RTS, and BSS treatments in the 2011/2012 and 2012/2013 growing seasons.

\begin{tabular}{|c|c|c|c|c|c|c|c|c|c|}
\hline Year & Treatment & $\begin{array}{c}\text { Sowing } \\
\text { (BBCH00) }\end{array}$ & $\begin{array}{l}\text { Emergence } \\
\text { (BBCH10) }\end{array}$ & $\begin{array}{l}\text { Wintering } \\
\text { (BBCH23) }\end{array}$ & $\begin{array}{c}\text { Revival } \\
\text { (BBCH23) }\end{array}$ & $\begin{array}{l}\text { Jointing } \\
\text { (BBCH31) }\end{array}$ & $\begin{array}{l}\text { Heading } \\
\text { (BBCH54) }\end{array}$ & $\begin{array}{c}\text { Filling } \\
\text { (BBCH73) }\end{array}$ & $\begin{array}{c}\text { Maturity } \\
\text { (BBCH92) }\end{array}$ \\
\hline \multirow{4}{*}{$2011 / 2012$} & NTS & October-11 & October-20 & November-29 & March-7 & April-8 & May-2 & May-18 & June-11 \\
\hline & DTS & October-11 & October-21 & November-29 & March-4 & April-6 & April-30 & May-16 & June-11 \\
\hline & RTS & October-11 & October-21 & November-29 & March-4 & April-6 & April-30 & May-16 & June-10 \\
\hline & BSS & October-11 & October-22 & November-29 & March-3 & April-7 & May-1 & May-16 & June-10 \\
\hline \multirow{4}{*}{$2012 / 2013$} & NTS & October-10 & October-19 & November-28 & March-5 & April-8 & May-6 & May-22 & June-11 \\
\hline & DTS & October-10 & October-20 & November-28 & March-3 & April-6 & May-5 & May-20 & June-11 \\
\hline & RTS & October-10 & October-20 & November-28 & March-3 & April-6 & May-5 & May-20 & June- 10 \\
\hline & BSS & October-10 & October-19 & November-28 & March-2 & April-7 & May-6 & May-21 & June-10 \\
\hline
\end{tabular}

\subsection{Tiller Development}

The productive tillers per hectare at the maturity stage in both seasons were affected by the tillage and sowing modes (Table 3). BSS was significantly higher than the other treatments, with average plant numbers of $657.0 \times 10^{4} \cdot \mathrm{ha}^{-1}$ and $799.8 \times 10^{4} \cdot \mathrm{ha}^{-1}$ in the $2011 / 2012$ and 2012/2013 growing seasons, respectively, followed by DTS, whose numbers were significantly higher than those of RTS and NTS in both growing seasons. However, no significant difference was found between NTS and RTS in the two growing seasons.

Table 3. Effect of seeding and tillage methods on population tillers of winter wheat for the four treatments.

\begin{tabular}{|c|c|c|c|c|c|c|c|c|c|}
\hline \multirow{2}{*}{ Year } & \multirow{2}{*}{ Treatment } & \multicolumn{7}{|c|}{ Dynamic of Tillers $/\left(10^{4} \cdot \mathrm{ha}^{-1}\right)$} & \multirow{2}{*}{$\begin{array}{l}\text { Earbearing Tiller } \\
\text { Percentage }\end{array}$} \\
\hline & & Basic Seedlings & Before Wintering & Revival & Jointing & Heading & Filling & Maturity & \\
\hline \multirow{4}{*}{$2011 / 2012$} & NTS & $607.7 \mathrm{aA}$ & $1146.3 \mathrm{bB}$ & $1300.4 \mathrm{dC}$ & $2279.1 \mathrm{cC}$ & $1254.8 \mathrm{bB}$ & $641.9 \mathrm{bB}$ & $554.7 \mathrm{cC}$ & 24.3 \\
\hline & DTS & $516.7 \mathrm{bB}$ & $1716.1 \mathrm{aA}$ & $1787.3 \mathrm{bB}$ & $2460.1 \mathrm{bB}$ & $1199.4 \mathrm{cBC}$ & $629.1 \mathrm{bB}$ & $587.9 \mathrm{bB}$ & 23.9 \\
\hline & RTS & $514.5 \mathrm{bB}$ & $1639.6 \mathrm{aA}$ & $1752.6 \mathrm{cB}$ & $2404.8 \mathrm{bB}$ & $1185.2 c \mathrm{C}$ & $594.6 \mathrm{cC}$ & $548.4 \mathrm{cC}$ & 22.8 \\
\hline & BSS & $472.3 \mathrm{bB}$ & $1727.5 \mathrm{aA}$ & $1988.4 \mathrm{aA}$ & $3096.1 \mathrm{aA}$ & $1441.2 \mathrm{aA}$ & $790.2 \mathrm{aA}$ & $657.0 \mathrm{aA}$ & 21.2 \\
\hline \multirow{4}{*}{$2012 / 2013$} & NTS & $610.9 \mathrm{aA}$ & $949.6 \mathrm{dD}$ & $1185.1 \mathrm{cC}$ & $1985.7 \mathrm{dC}$ & $1139.2 \mathrm{cC}$ & $757.5 \mathrm{dC}$ & $705.8 \mathrm{cC}$ & 35.5 \\
\hline & DTS & $562.5 \mathrm{bAB}$ & 1484.5aA & 1788.5aA & $2397.2 \mathrm{bB}$ & 1193.4bB & $810.0 \mathrm{bB}$ & $738.8 \mathrm{bB}$ & 30.8 \\
\hline & RTS & $547.5 \mathrm{bAB}$ & $1339.3 \mathrm{bB}$ & $1610.0 \mathrm{bB}$ & $2315.4 \mathrm{cB}$ & $1151.7 \mathrm{cBC}$ & $775.9 \mathrm{cC}$ & $717.8 \mathrm{cC}$ & 31.0 \\
\hline & BSS & $528.4 \mathrm{bB}$ & $1232.8 \mathrm{cC}$ & $1643.5 \mathrm{bB}$ & 3199.7aA & $1506.7 \mathrm{aA}$ & $930.0 \mathrm{aA}$ & $799.8 \mathrm{aA}$ & 25.0 \\
\hline
\end{tabular}

\subsection{Dry Matter Accumulation}

Dry matter accumulation is a prerequisite for grain yield formation. The dryer the mass accumulated, the more assimilate transported to the grain, and the higher the grain yield. The dry matter of winter wheat for different tillage and sowing methods was consistent between the two growing seasons. The highest to lowest dry mass accumulation values were as follows: BSS > DTS $>$ RTS > NTS. The dry matter accumulative rate of BBS was the highest at all developmental stages in both growing seasons. The greatest dry matter accumulative period occurred at the heading to maturity period for all treatments, with $47.7 \%, 43.7 \%, 43.6 \%, 42.3 \%$ and $49.3 \%, 45.3 \%, 45.4 \%, 44.7 \%$ dry matter accumulated in the 2011/2012 and 2012/2013 growing seasons for NTS, DTS, RTS, and BSS, respectively (Table 4).

Table 4. Effect of seeding and tillage methods on dry matter accumulation of winter wheat for the four treatments.

\begin{tabular}{|c|c|c|c|c|c|c|c|c|c|c|c|c|}
\hline \multirow[b]{2}{*}{ Year } & \multirow[b]{2}{*}{ Treatment } & \multicolumn{11}{|c|}{ Dry matter accumulation of each growing stage $\left(\mathrm{kg} \cdot \mathrm{ha}^{-1}\right)$} \\
\hline & & $\begin{array}{c}\text { Before } \\
\text { Wintering }\end{array}$ & $\%$ & Wintering & $\%$ & $\begin{array}{c}\text { Revival to } \\
\text { jointing }\end{array}$ & $\%$ & $\begin{array}{l}\text { Jointing to } \\
\text { Heading }\end{array}$ & $\%$ & $\begin{array}{l}\text { Heading to } \\
\text { Maturity }\end{array}$ & $\%$ & $\begin{array}{l}\text { Whole Growth } \\
\text { Period }\end{array}$ \\
\hline \multirow{4}{*}{$2011 / 2012$} & NTS & 899.0 & 6.0 & -240.2 & -1.6 & 1830.5 & 12.3 & 5286.0 & 35.5 & 7095.9 & 47.7 & $14,871.1$ \\
\hline & DTS & 1084.0 & 6.9 & -280.2 & -1.8 & 2545.2 & 16.2 & 5473.4 & 34.9 & 6858.4 & 43.7 & $15,680.7$ \\
\hline & RTS & 1075.3 & 7.1 & -290.2 & -1.9 & 2450.0 & 16.1 & 5370.7 & 35.3 & 6631.9 & 43.6 & $15,222.5$ \\
\hline & BSS & 1165.1 & 6.7 & -455.2 & -2.6 & 3065.3 & 17.7 & 6197.9 & 35.9 & 7305.5 & 42.3 & $17,278.6$ \\
\hline \multirow{4}{*}{$2012 / 2013$} & NTS & 1126.6 & 5.9 & -250.8 & -1.3 & 2602.2 & 13.7 & 6141.5 & 32.4 & 9362.3 & 49.3 & $18,981.7$ \\
\hline & DTS & 1270.3 & 6.4 & -273.7 & -1.4 & 3561.4 & 17.9 & 6314.0 & 31.8 & 8989.3 & 45.3 & $19,861.3$ \\
\hline & RTS & 1243.1 & 6.3 & -279.6 & -1.4 & 3481.1 & 17.7 & 6288.9 & 32.0 & 8939.5 & 45.4 & $19,673.1$ \\
\hline & BSS & 1301.0 & 5.9 & -423.6 & -1.9 & 4168.1 & 19.0 & 7050.2 & 32.2 & 9795.1 & 44.7 & $21,890.8$ \\
\hline
\end{tabular}




\subsection{Yield and Yield Components}

Table 5 shows the grain yield and its components under different tillage and sowing methods. There were significant differences among the treatments in the two growing seasons, with the grain yield of BSS the highest at $7599.0 \mathrm{~kg} \cdot \mathrm{ha}^{-1}$ in 2011/2012 and $9763.3 \mathrm{~kg} \cdot \mathrm{ha}^{-1}$ in the 2012/2013, which was $11.55 \%, 16.17 \%, 20.16 \%$ and $13.01 \%, 15.68 \%, 21.88 \%$ higher than DTS, RTS, and NTS in 2011/2012 and $2012 / 2013$, respectively. The grain yield of NTS was significantly decreased when compared with other treatments. DTS was significantly higher than RTS in 2011/2012, while there was no significant difference between the two treatments in the 2012/2013 growing season.

Little difference was observed for the 1000-kernel weight for the two growing seasons, with the exception of NTS, which was significantly lower than the other three treatments in 2012/2013. The order from highest to the lowest was DTS, RTS, BSS, and NTS in both growing seasons.

There was no significant difference for the kernel numbers per spike among the four treatments in the two seasons, and it showed the following relationship: DTS $>$ RTS $>$ BSS $>$ NTS and RTS $>$ DTS > BSS > NTS in 2011/2012 and 2012/2013, respectively.

The spike number in both growing seasons was affected by the tillage and sowing modes. BSS was significantly higher than the other treatments, with the average spike numbers of $657.0 \times 10^{4} \cdot \mathrm{ha}^{-1}$ and $799.8 \times 10^{4} \cdot$ ha $^{-1}$ in the 2011/2012 and 2012/2013 growing seasons, respectively, followed by DTS, which was significantly higher than RTS and NTS in both growing seasons. However, no significant difference was found between NTS and RTS in the two seasons.

Table 5. Yield and yield components of winter wheat.

\begin{tabular}{|c|c|c|c|c|c|c|}
\hline Season & Treatment & $\begin{array}{l}\text { Productive Tillers } \\
\qquad\left(10^{4} \cdot \mathrm{ha}^{-1}\right)\end{array}$ & $\begin{array}{l}\text { Grains per } \\
\text { Spike }\end{array}$ & $\begin{array}{l}\text { 1000-kernel } \\
\text { Weight (g) }\end{array}$ & $\begin{array}{c}\text { Yield } \\
\left(\mathrm{kg} \cdot \mathrm{ha}^{-1}\right)\end{array}$ & $\begin{array}{l}\text { Harvest } \\
\text { Index }\end{array}$ \\
\hline \multirow{4}{*}{$2011 / 2012$} & NTS & $554.8 \mathrm{cC}$ & $29.0 a$ & $40.5 a$ & $6323.8 \mathrm{dD}$ & $0.43 \mathrm{~B}$ \\
\hline & DTS & $587.9 \mathrm{bB}$ & $30.0 \mathrm{a}$ & $40.5 a$ & $6812.4 \mathrm{bB}$ & $0.43 \mathrm{~B}$ \\
\hline & RTS & $548.4 c \mathrm{c}$ & $29.6 a$ & $40.4 a$ & $6541.5 \mathrm{cC}$ & $0.43 \mathrm{~B}$ \\
\hline & BSS & $657.0 \mathrm{aA}$ & $29.1 \mathrm{a}$ & $40.2 a$ & $7599.0 \mathrm{aA}$ & $0.44 \mathrm{~A}$ \\
\hline \multirow{4}{*}{$2012 / 2013$} & NTS & $705.8 \mathrm{dC}$ & $30.8 \mathrm{a}$ & $37.1 \mathrm{bB}$ & $8010.3 c C$ & $0.42 \mathrm{cC}$ \\
\hline & DTS & $738.8 b B$ & $31.4 \mathrm{a}$ & $39.4 \mathrm{aA}$ & $8639.7 \mathrm{bB}$ & $0.44 \mathrm{bB}$ \\
\hline & RTS & $717.8 \mathrm{cC}$ & $31.7 \mathrm{a}$ & $39.2 \mathrm{aA}$ & $8439.7 \mathrm{bB}$ & $0.43 \mathrm{bB}$ \\
\hline & BSS & 799.8aA & $31.3 a$ & 39.1aA & 9763.3aA & $0.45 \mathrm{~A}$ \\
\hline
\end{tabular}

\section{Discussion}

For the four treatments, the grain yields of the winter wheat were as follows: BSS > DTS > RTS > NTS. BSS was significantly higher than the other treatments, with the highest productive spikes per hectare. No significant difference was observed for the number of grains per spike. A significantly lower 1000-kernel weight was found for NTS. Our results strongly suggest that BSS was the most suitable for winter wheat planting in North China. The highest grain yield was possibly the result of the increased spike number per hectare. The high effective tiller numbers in BSS were most likely due to the even distribution of the seeds in the field, which would result in evenly distributed plant stands (Figure 2) and higher stand uniformity.

\subsection{Stand Uniformity}

Stand uniformity has been recommended as an important aspect to consider for high yield formation [13]. Weiner et al. [18] reported that increased density causes an increase in the competition, and the size inequality of non-uniform patterns was higher than in a uniform spatial pattern. In non-uniform stands of field crops, bigger or taller plants gained a competitive advantage over the smaller or shorter ones, whose growth was suppressed, resulting in the decline of the number of fertile spikes per unit area [19] and the failure to counterbalance losses $[13,20]$. This indicated that non-uniform stands may yield less uniform stands at a higher plant population density [21]. 
The stand uniformity of the four treatments in the 2011/2012 and 2012/2013 growing seasons was compared. As illustrated in Figure 3, the uniformity of BSS was higher than the other treatments in both growing seasons, and it was significantly higher in the 2012/2013 growing season. BBS was more uniform than the other row spacing treatments, which could be exclusively explained by the even dispersal of the seeds throughout the whole field in the BSS treatment. Xue et al. [11] demonstrated that reducing row spacing or improving seed uniformity within the rows could decrease the plant-to-plant variability. This was also confirmed by the "wide-precision" planting pattern in which single grains were separated from each other, which resulted in more uniformity than that using the narrow row spacing $[9,12]$.

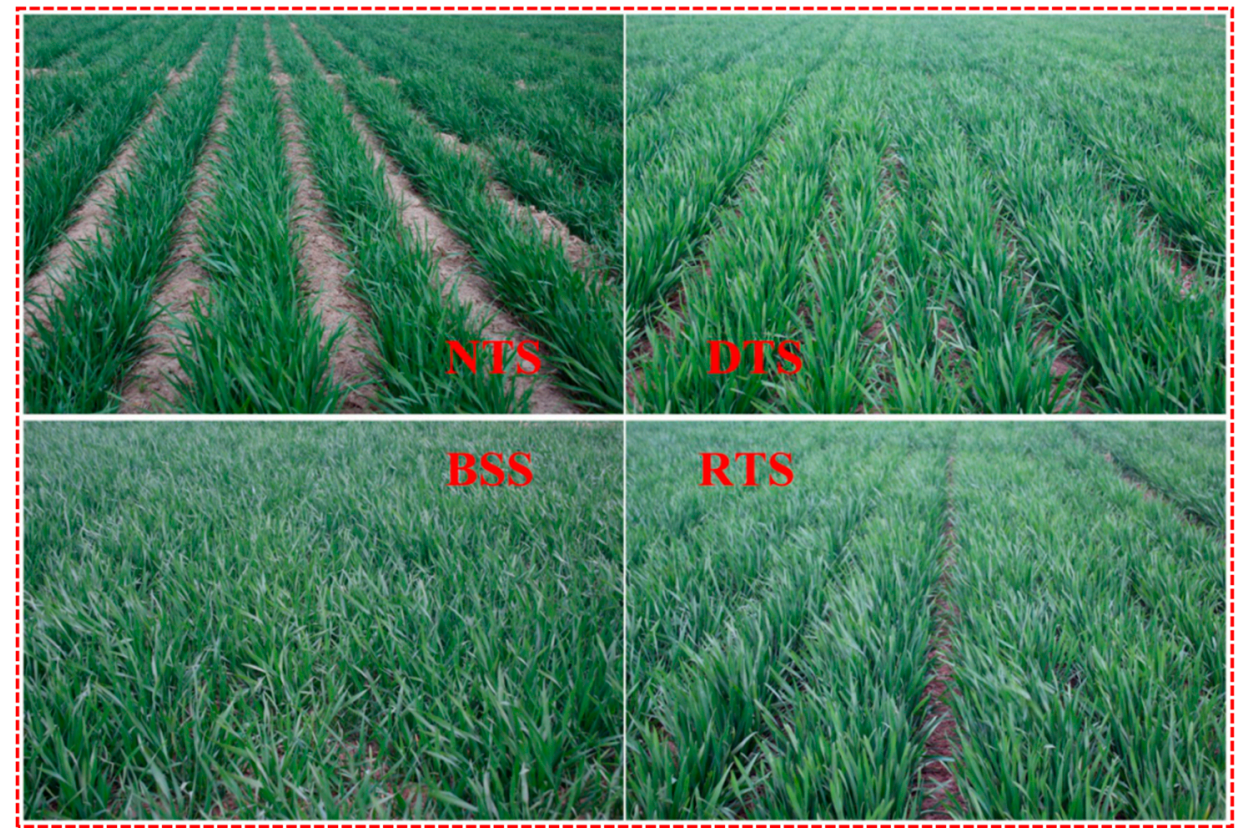

Figure 2. Seedling growth of winter wheat after revival under different tillage and seeding methods.

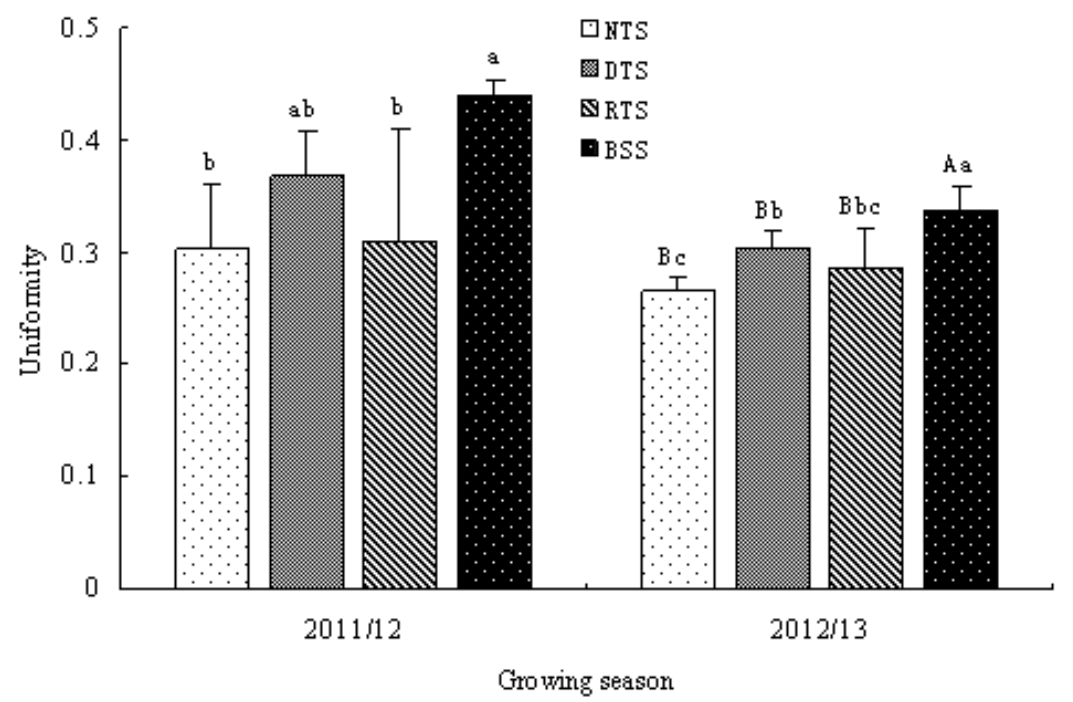

Figure 3. Stand uniformity of the NTS, RTS, DTS, and BSS treatments 


\subsection{Uniformity Can Facilitate a Reasonable Canopy Structure with a More Uniform Distribution of Leaves in the Canopy}

Our report also demonstrates that uniformity could help establish a reasonable canopy structure for winter wheat. The internode length below the spike was in the order of DTS > BSS > NTS > RTS; the first internode length above the ground had the order of NTS $>$ RTS $>$ BSS $>$ DTS; the order of the average middle internode length appeared in the order of DTS $>$ BSS $>$ RTS $>$ NTS (data not shown). This indicated that the higher-density tillering of BSS was not accompanied by the longest internodes below the spike, the first internodes above the ground, nor the shortest of the average middle internodes, and the leaves were distributed more evenly.

For the plant height component index $\left(\mathrm{I}_{\mathrm{L}}\right)$, the lowest $\mathrm{I}_{\mathrm{L}}$ was not observed in BSS. The order from high to low was DTS (0.593), BSS (0.592), NTS (0.589), and RTS (0.575). A higher $\mathrm{I}_{\mathrm{L}}$ indicated that the leaves in the top and middle of the plants were comparatively sparse, and this would be favorable for sunlight penetration, whereas the leaves in the bottom were compact, suggesting that more light would be intercepted. A higher $\mathrm{I}_{\mathrm{L}}$ and shorter first internodes could also improve the resistance to lodging [17], and no lodging was observed for BSS in the two growing seasons.

A higher MLLA means more erective leaves. After the jointing stage, the leaves of BSS were more erective than the others (Figure 4). The MLLA of BSS was the highest and was significantly higher than RTS at the jointing and grain filling stages and NTS at the heading stage. The leaves of the BSS were more erective than the others, which would lead to a more even distribution of the sunlight.

The canopy temperature for the four treatments was NTS > RTS > DTS > BSS at the grain filling stage. Since the lower canopy temperature could enhance the grain yield and alleviate the drought or the heat stress [22], these results indicated that BSS could be appropriate in the areas where these adverse events frequently occur. For example, most European countries have experienced increased air temperature in production areas $[23,24]$. Adverse weather events will become more frequent in the future, and wheat yield reduction will occur [25].
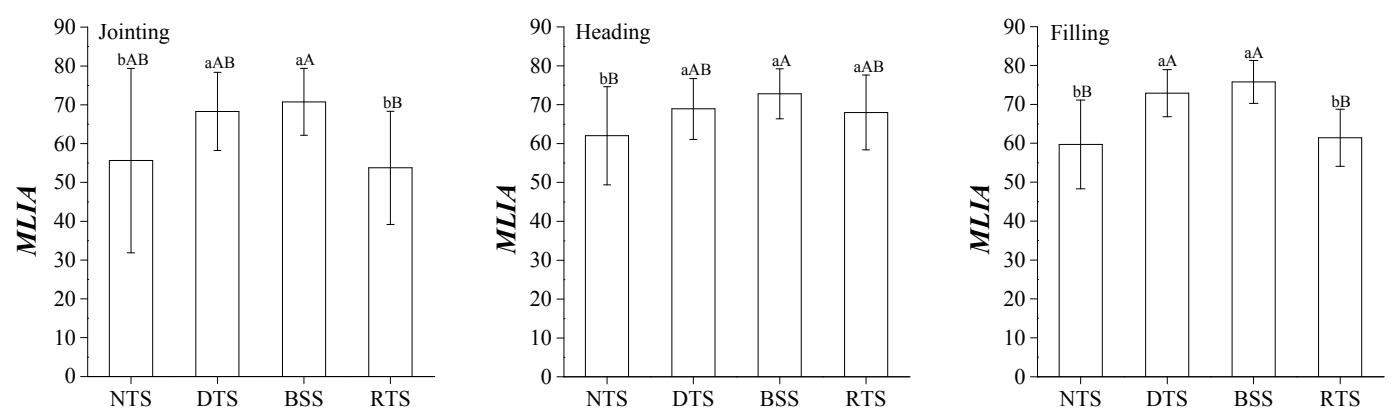

Figure 4. Mean leaf inclination angle of winter wheat at jointing, heading, and grain filling stages.

\subsection{More Tillers Obtained When the Stand Was Uniform}

Tiller number is one of the determinant traits for wheat grain yield. Stand uniformity of wheat could increase the fertile spikes. Optimum row spacing can help optimize the tillering capacity and increase wheat grain yield [26]. Previous research has indicated that more spikes per unit area can be obtained when row spacing is decreased, and a higher wheat yield with narrow row spacing can be the result of a significant increase in productive tillers with a concomitant decrease in grain count and grain weight [10]. More spikes per unit area were also found with the more uniform "wide-precision" planting pattern [9,12] and where there was more seed uniformity within the rows [11].

As shown in Figure 5, the leaves of BSS were horizontally extended, whereas the leaves for the other treatments were more erect, which would suggest that more radiation would be intercepted by BSS, leading to more assimilate production, and more tillers produced.

Plants can detect their neighbors by sensing the changes in the ratio of red (R) to far-red (FR) photons caused by the absorptance of red light and the high reflectance and transmittance of far-red 
light with phytochromes $[27,28]$ at the early development stage before shading [29]. Under low R:FR, eudicots produced more erect leaves [30], and the entire shoot of forage grasses was more erect [31]. A low R:FR may reduce tillering or dry matter accumulation before any serious reduction in the light intercepted per plant [32]. In our research, for RTS, DTS, and NTS, winter wheat was locally crowded with a high density, and fewer tillers and more erect leaves were observed compared with BSS, for which the seeding was evenly distributed and resulted in a lower local stand density.

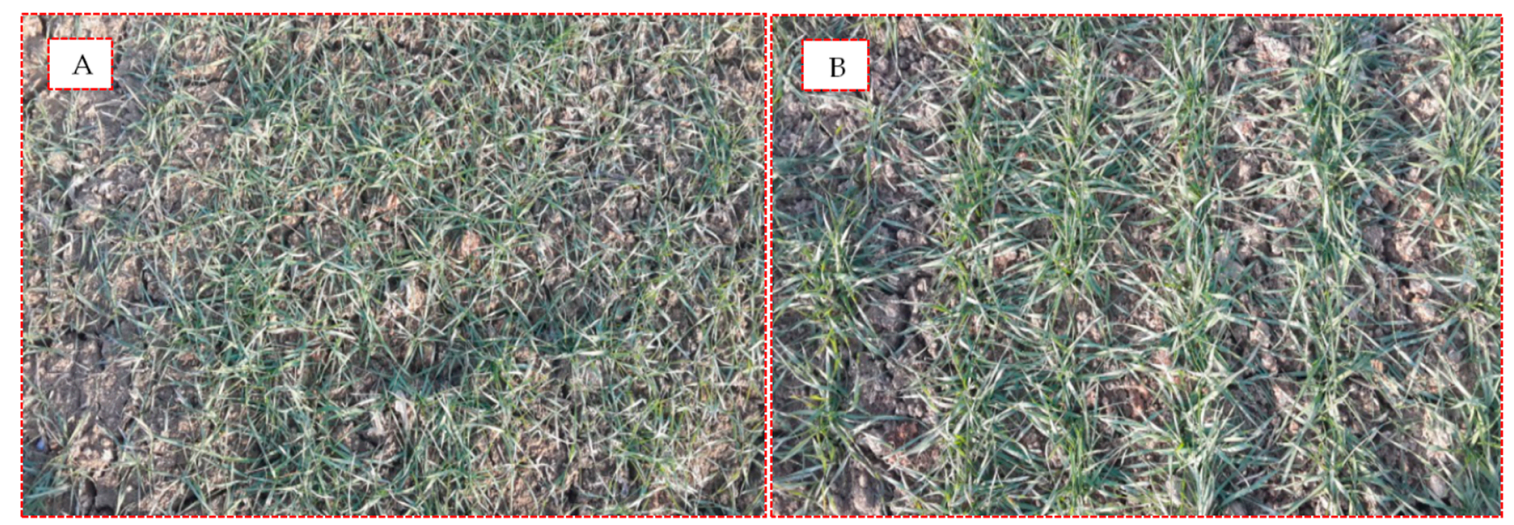

Figure 5. The leaves of BSS (A) before wintering were more horizontal than those of RTS (B).

At the jointing stage, heading stage, and grain filling stage, the leaves of BSS were more erective than the others. Erect leaves can increase the wheat growth rate and the grain yield [33]. With a dense canopy, erect leaves can facilitate sunlight penetration to the bottom leaves which thereby enhance photosynthesis; conversely, the shading of horizontal leaves leads to the premature senescence of the bottom leaves and a reduction in photosynthetic activity [34,35].

The more even sunlight distribution in BSS suggests more assimilates, which would lead to more tillerings surviving.

\subsection{BSS Can Improve Grain Yield without Reducing Kernel per Spike and Kernel Weight}

BSS improved the grain yield without comprising the kernels per spike and the kernel weight since no significant difference was detected, in contrast with the results of narrow row spacing. In wheat planted in conventional rows, decreased row spacing increases the population density. However, too narrow a row space will result in yield losses because of the decreased number of grains per spike and 1000-grain weight due to severe inter-row competition [26]. When the increased tillers cannot compensate for the losses by decreasing the kernel count per spike and the kernel weight, yield losses are inevitable.

The uniformity of the stands may alleviate these losses. Zhao et al. [12] and Xue et al. [11] also reported that more uniformity could increase grain yield with no decline in the kernels per spike and 1000-kernel weight. One reason could be attributed to the reasonable population architecture and canopy structure and the higher efficiency in the utilization of sunlight. The highest leaf area index (LAI) at the grain filling stage and the highest dry matter accumulation reported in this study support the high efficiency of sunlight use in BSS.

In the current study, BSS had the highest LAI at all the development stages (Figure 6). Leaf area is important for light interception and photosynthesis [36]. For the four treatments, the LAI increased slowly before winter, increased quickly after the revival period, and reached the maximum value around the heading period (200-210 day after seeding), then decreased dramatically in all the treatments in both growing seasons, exhibiting the trend BSS $>$ DTS $>$ DRS $>$ NTS. BSS achieved its maximum LAI earlier than the others, followed by DTS and RTS, and NTS was the latest. The LAI of BSS was the highest before and after the wintering period in the two growing seasons at jointing period; BSS was $9.01 \%, 13.57 \%$, and $23.06 \%$ higher than DTS, RTS, and NTS in the 2011/2012 growing 
season. Moreover, the difference increased after the jointing period and BSS reached a maximum of 8.23, which was $29.58 \%, 33.97 \%$, and $49.49 \%$ higher than DTS, RTS, and NTS in 2011/2012.

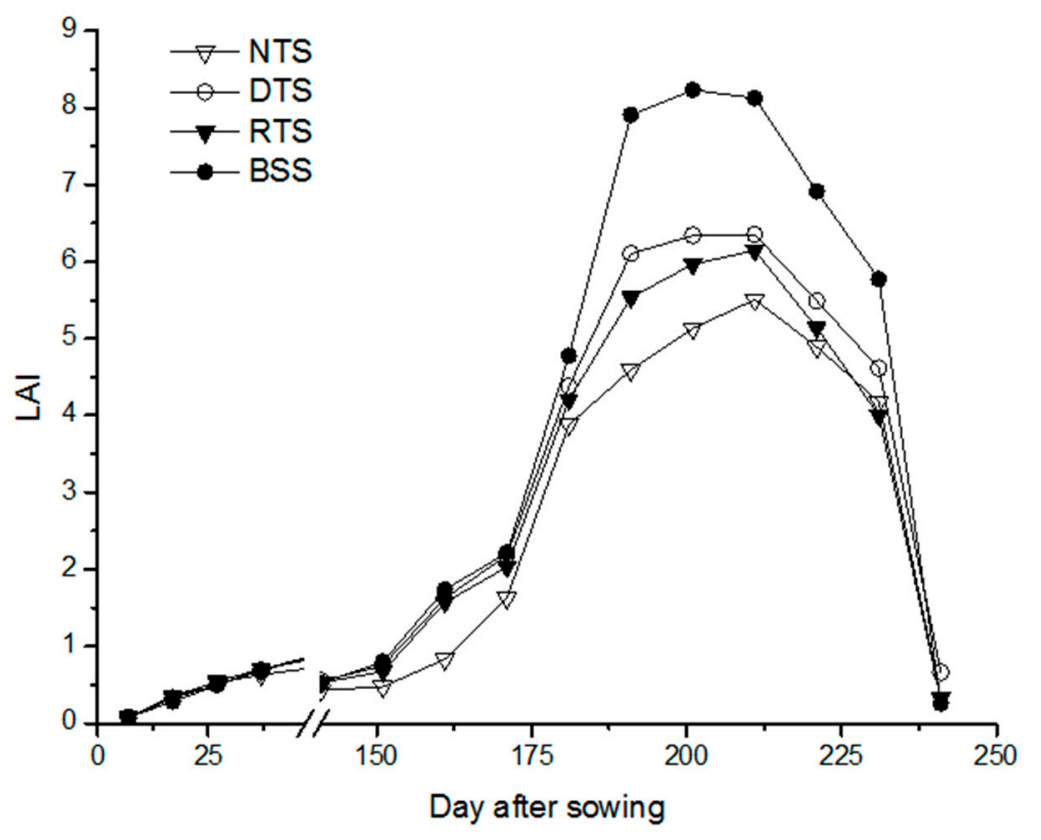

Figure 6. The leaf area index of winter wheat in 2011/2012 growing season for the four treatments.

The same results were also found in the more uniform wide-precision planting, which had a higher LAI in the late growing seasons and higher photosynthetically active radiation (PAR) capture ratios, in contrast with conventional planting [12].

Another important reason for the high grain yield of BSS is that it achieved the highest dry matter accumulation (DMA). Previous studies have shown that grain yield is mainly associated with the pre-anthesis assimilate contribution to grain filling and a greater DM translocation efficiency [37]. However, Shearman [38] and Meng [39] reported that because of the recent genetic gains in wheat breeding, more dry matter over the entire growing season was important to achieve high grain yield, further clarifying the positive correlation between grain yield and DM accumulation post-anthesis. In this study, the dry matter of BSS was the highest in both growing seasons, with more DMA pre-anthesis, and the contribution of the post-anthesis DM to grain can improve grain filling and thus increase grain yield. Furthermore, the DMA from the jointing to the heading stage was the highest in the two growing seasons, which is most important in determining the number of fertile spikelets at anthesis and final grain yield.

This is in agreement with studies by Xue [11] and Zhao [12], in which evenly distributed seeds could improve the DMA. Zhao [12] reported that the more uniform wide-precision planting had a higher DMA at the milking stage, and Xue [11] also found that the uniformity could facilitate the pre-anthesis assimilate translocation. Our results suggest that the uniformity of BSS could improve both pre-anthesis and post-anthesis dry matter accumulation, enhance grain filling, and increase the jointing to heading period dry matter accumulation, which could maintain the kernel number per spike, even at a high density of spikes per unit area.

More uniformity was also favorable to secondary root development, and this is conducive to nutrient uptake, increasing the nutrient utilization efficiency. The much higher LAI of BSS could decrease evaporative losses, increase water, light, and nutrient utilization efficiency, ensure high dry matter accumulation, and attenuate the interplant competition for assimilates. Uniformity could increase the relative humidity in the canopy, thus lowering the canopy temperature [11]. This would explain why BSS did not experience reduced kernels per spike and 1000-kernel weight. 


\subsection{Stand Uniformity Can Facilitate Reproductive Relocation}

BSS had (significantly) the highest harvest index (HI) in both growing seasons when compared with the other treatments. In the four treatments, $\mathrm{HI}$ increased along with stand uniformity. This further confirmed that stand uniformity was an important aspect of high yield production [13,40]. With uneven stands, intraspecific competition would be elevated, and the greater investment of dry matter in non-reproductive structures at the expense of grain would result in a lower HI [41].

\subsection{Seedlings}

It has been reported that non-uniform plant depths caused by heavy surface residues of no-tillage farming always results in poor emergence, thin stands, slow vegetative growth, and decreased grain yield [42,43]. $\mathrm{Li}[44]$ reported that the maize stubble returning from no-tillage farming had a negative effect on seed emergence, reduced the lower tillers per unit area, and, consequently, had a low grain yield. The same result was also observed by Kong [45], who indicated that a lower grain yield was due to the lower tillers per unit area. Our result was different from previous studies in that NTS had a higher emergence rate, plant stands, and basic seedlings [44]. For NTS, the soil was strip rotary tilled with a width of $10 \mathrm{~cm}$ every $30 \mathrm{~cm}$. This tillage method is close to no-tillage farming, since no more than $1 / 3$ of the land was tilled. The seeds were sown in the furrow between the two ridges. When it was mechanically ridged, the soil fell down into the furrow. Thus, the sowing depth of NTS was higher than the other treatments, and the seed coverage ratio was the highest.

BSS had the lowest emergence rate, thin stands, and the lowest basic seedlings compared with the others in the two growing seasons. In the 2011/2012 growing season, the soil was loose after fertilizing, sowing, rotary tilling, and compacting. For BSS, about $10 \%$ of the seeds were uncovered in the $0-10 \mathrm{~cm}$ soil layer and the average sowing depth was the highest. In the next growing season, extra compaction was applied, while no significant differences in sowing depth were observed between RTS, DTS, and BSS. For the DTS treatment, after sowing, the soil was loose and uneven, the seed cover rate was lower than that of RTS, and after additional compaction was applied, the seed cover rate was higher than that of RTS.

NTS and BSS were completed with plowing, fertilizing, soil preparing, sowing, and compacting at one time, and were more efficient than RTS and DTS. Since in DTS, the soil was deep and loose to $40-50 \mathrm{~cm}$, it was less efficient than RTS.

It is widely known that a fast, uniform, and complete seedling establishment is crucial for plant growth and initial dry matter production. Further improvement was required for the BSS machine to achieve high grain yield because BSS had the lowest emergence rate, thin stands, and the lowest basic seedlings when compared with the other treatments.

\subsection{The Variety}

The variety used in this experiment, the Jimai 22, was once the most planted winter wheat in China. It has high tillering and large spikes. According to the discussion above, this even seed distribution could increase the crop yield by increasing the stand uniformity, which resulted in higher tillers, LAI, dry matter accumulation, and HI, which was applicable to the other wheat cultivars. We can infer that it is not only applied in China but also the other regions.

Moreover, the spatial uniformity of wheat may reduce the need for applications of herbicides and pesticides. The uniformity of the plant distribution resulted in weed suppression [15] by maximizing its density over that of weeds [46]. The competition between the wheat and weeds resulted in greater sensitivity to soil biota because of the plant-soil feedback [47]. These results suggest that less herbicide and pesticide are needed. 


\section{Conclusions}

BSS was the most suitable for winter wheat production in North China. It resulted in higher productive tillers per hectare without significantly reducing the kernels per spike and 1000-grain weight. The higher uniformity resulted in increased grain yield. The stand uniformity played a crucial role in the grain yield production, which could result in higher LAI, dry matter accumulation, reproductive allocation, and a reasonable canopy structure. For BSS, the lower emergence rate caused by the lower effective seed cover ratio and non-uniform seeding depth can be improved by increasing the seeding rate, implementing compaction after sowing, and further improvement of the machine.

Author Contributions: Y.Z. was responsible for the initial analysis, interpretation of the data, and writing of the manuscript. F.C., H.Z., X.Y. were responsible for planning, design of the deep vertical lime practice, site selection, analysis, and interpretation of results. Q.W. and G.C. participated in the planning, design, interpretation of results, and manuscript preparation.

Funding: This project was partly funded by the Special Fund for Agro-scientific Research in the Public Interest (agriculture) (201103001), and partially financed by National Key Technology Research and Development Program of the Ministry of Science and Technology of China (2012BAD20B00).

Acknowledgments: The authors would like to thank Zhanguo Xin in USDA-ARS for the English correction and scientific suggestion on the manuscript.

Conflicts of Interest: The authors have no conflict of interest.

\section{References}

1. Wu, D.; Yu, Q.; Lu, C.; Hengsdijk, H. Quantifying production potentials of winter wheat in the North China Plain. Eur. J. Agron. 2006, 24, 226-235. [CrossRef]

2. Chen, S.Y.; Zhang, X.Y.; Sun, H.Y.; Shao, L.W. Cause and mechanism of winter wheat yield reduction under straw mulch in the North China Plain. Chin. J. Eco-Agric. 2013, 21, 519-525. [CrossRef]

3. Qin, H.L.; Gao, W.S.; Yue-Cun, M.A.; Li, M.A.; Yin, C.M. Effects of Subsoiling on Soil Moisture under No-tillage 2 Years Later. Sci. Agric. Sin. 2008, 7, 88-95.

4. Meirong, L.; Li, Z.; Zhang, T.; Ning, T.; Zhao, J.; Li, H. Effects of minimum or no-tillage system and straw returning on extreme soil moisture and yield of winter wheat. Trans. Chin. Soc. Agric. Eng. 2010, 26, 41-46.

5. BlancoCanqui; DeClerck; Gatere, Conservation agriculture and ecosystem services: An overview. Agric. Ecosyst. Environ. 2014, 187, 87-105. [CrossRef]

6. Li, Y.; Wu, J.; Ming, H.; Yao, Y.; Zhang, C.; Cai, D.; Ke, J. Effects of different tillage systems on photosynthesis characteristics of flag leaf and water use efficiency in winter wheat. Trans. Chin. Soc. Agric. Eng. 2006, 22, 44-48.

7. Han, B.; Li, Z.; Yun, W.; Ning, T.; Zheng, Y.; Shi, Z. Effects of soil tillage and returning straw to soil on wheat growth status and yield. Trans. Chin. Soc. Agric. Eng. 2007, 23, 48-53.

8. Zheng, C.Y.; Cui, S.M.; Dong, W.; Zhen-Wen, Y.U.; Zhang, Y.L. Effects of Soil Tillage Practice on Dry Matter Production and Water Use Efficiency in Wheat. Acta Agron. Sin. 2011, 37, 1432-1440. [CrossRef]

9. Bian, C.; Ma, C.; Liu, X.; Chao, G.; Liu, Q.; Yan, Z.; Ren, Y.; Li, Q. Responses of Winter Wheat Yield and Water Use Efficiency to Irrigation Frequency and Planting Pattern. PLoS ONE 2016, 11, e0154673. [CrossRef] [PubMed]

10. Liu, Z.; Qin, A.; Zhao, B.; Ata-Ul-Karim, S.T.; Xiao, J.; Sun, J.; Ning, D.; Liu, Z.; Nan, J.; Duan, A. Yield Response of Spring Maize to Inter-Row Subsoiling and Soil Water Deficit in Northern China. PLoS ONE 2016, 11, e0153809. [CrossRef] [PubMed]

11. Xue, Y.; Zhang, Y.; Huang, Q. Effects of nar-row row spacing and uniform sowing on canopy environment, individualplant traits, and biomass production in late-sowing winter wheat. Acta Ecol. Sin. 2015, 35, 5545-5555.

12. Zhao, D.; Shen, J.; Lang, K.; Liu, Q.; Li, Q. Effects of irrigation and wide-precision planting on water use, radiation interception, and grain yield of winter wheat in the North China Plain. Agric. Water Manag. 2013, 118, 87-92.

13. Fasoula, D.A.; Fasoula, V.A. Competitive ability and plant breeding. In Plant Breeding Reviews; John Wiley \& Sons, Inc.: New York, NY, USA, 1997; pp. 89-138. 
14. Chen, C.; Karnes, N.; Dave, W.; Malvern, W. Hard Red Spring Wheat Response to Row Spacing, Seeding Rate, and Nitrogen. Agron. J. 2008, 100, 1296-1302. [CrossRef]

15. Kristensen, L.; Olsen, J.; Weiner, J.; Griepentrog, H.W.; Nørremark, M. Describing the spatial pattern of crop plants with special reference to crop-weed competition studies. Field Crops Res. 2006, 96, 207-215. [CrossRef]

16. Zhai, Y.; Wei, Y.; Zhang, H.L.; Chen, F. Effect of seeding and tillage methods on population quality and yield of winter wheat in North China. J. Triticeae Crop. 2016, 36, 1174-1182.

17. Wei, X.; Wu, C.S. Architectural Analysis of Plant Height of Common Wheat (Triticum aestivum L.). J. Nanjing Agric. Univ. 1983, 1, 13-21.

18. Weiner, J.; Stoll, P.; Muller-Landau, H.; Jasentuliyana, A. The effects of density, spatial pattern, and competitive symmetry on size variation in simulated plant populations. Am. Nat. 2001, 158, 438-450. [CrossRef]

19. Schwinning, S.; Weiner, J. Mechanisms determining the degree of size asymmetry in competition among plants. Oecologia 1998, 113, 447-455. [CrossRef]

20. Ford, J.H.; Hicks, D.R. Corn Growth and Yield in Uneven Emerging Stands. J. Prod. Agric. 1992, 5, 185. [CrossRef]

21. Tollenaar, M.; Dwyer, L. Physiology of maize. In Crop Yield; Springer: Salmon Tower Building, NY, USA, 1999; pp. 169-204.

22. Gautam, P.; Xue, Q.; Jessup, K.E.; Rudd, J.C.; Liu, S.; Mahan, J.R. Cooler Canopy Contributes to Higher Yield and Drought Tolerance in New Wheat Cultivars. Crop Sci. 2014, 54, 2275-2284.

23. Palut, M.P.J.; Canziani, O.F. Contribution of Working Group II to the Fourth Assessment Report of the Intergovernmental Panel on Climate Change; Cambridge University Press: Cambridge, UK, 2007.

24. Kristensen, K.; Schelde, K.; Olesen, J.E. Winter wheat yield response to climate variability in Denmark. J. Agric. Sci. 2011, 149, 33-47. [CrossRef]

25. Trnka, M.; Rötter, R.P.; Ruiz-Ramos, M.; Kersebaum, K.C.; Olesen, J.E.; Žalud, Z.; Semenov, M.A. Adverse weather conditions for European wheat production will become more frequent with climate change. Nat. Clim. Chang. 2014, 4, 637. [CrossRef]

26. Hussain, M.; Mehmood, Z.; Khan, M.B.; Farooq, S.; Dong-Jin, L.; Farooq, M. Narrow row spacing ensures higher productivity of low tillering wheat cultivars. Int. J. Agric. Biol. 2012, 14, 413-418.

27. Smith, H. Physiological and Ecological Function within the Phytochrome Family. Annu. Rev. Plant Physiol. Plant Mol. Biol. 2003, 46, 289-315. [CrossRef]

28. Smith, H.; Whitelam, G.C. The shade avoidance syndrome: Multiple responses mediated by multiple phytochromes. Plant Cell Environ. 2010, 20, 840-844. [CrossRef]

29. Casal, J.J.; Sanchez, R.A.; Deregibus, V.A. The effect of plant density on tillering: The involvement of R/FR ratio and the proportion of radiation intercepted per plant. Environ. Exp. Bot. 1986, 26, 365-371. [CrossRef]

30. Satter, R.L.; Wetherell, D.F. Photomorphogenesis in Sinningia speciosa, cv. Queen Victoria II. Stem Elongation: Interaction of a Phytochrome Controlled Process and a Red-Requiring, Energy Dependent Reaction. Plant Physiol. 1968, 43, 961-967. [CrossRef]

31. Casal, J.J.; Sanchez, R.A.; Gibson, D. The Significance of Changes in the Red/Far-Red Ratio, Associated with Either Neighbour Plants or Twilight, for Tillering in Lolium multiflorum Lam. New Phytol. 1990, 116, 565-572. [CrossRef]

32. Ballaré, C.L.; Sánchez, R.A.; Scopel, A.L.; Casal, J.J.; Ghersa, C.M. Early detection of neighbour plants by phytochrome perception of spectral changes in reflected sunlight. Plant Cell Environ. 2010, 10, 551-557.

33. Simon, M. Inheritance of flag-leaf angle, flag-leaf area and flag-leaf area duration in four wheat crosses. Theor. Appl. Genet. 1999, 98, 310-314. [CrossRef]

34. Thorne, G. Physiological factors limiting the yield of arable crops. In Potential Crop Production, A Case Study; Wareing, P.F., Cooper, J.P., Eds.; Heinemann Educational Books Limited: London, UK, 1971.

35. Borojevic, S.; Cupina, T.; Krsmanovic, M. Green area parameters in relation to grain yield of different wheat genotypes. Z. Pflanzenzucht. 1980, 84, 265-283.

36. Wells, R. Soybean growth response to plant density: Relationships among canopy photosynthesis, leaf area, and light interception. Crop Sci. 1991, 31, 755-761. [CrossRef]

37. Álvaro, F.; Isidro, J.; Villegas, D.; García del Moral, L.F.; Royo, C. Breeding effects on grain filling, biomass partitioning, and remobilization in Mediterranean durum wheat. Agron. J. 2008, 100, 361-370. [CrossRef] 
38. Shearman, V.J.; Sylvester-Bradley, R.; Scott, R.K.; Foulkes, M.J. Physiological processes associated with Wheat Yield Progress in the UK. Crop Sci. 2005, 45, 175-185.

39. Meng, Q.; Yue, S.; Chen, X.; Cui, Z.; Ye, Y.; Ma, W.; Tong, Y.; Zhang, F. Understanding dry matter and nitrogen accumulation with time-course for high-yielding wheat production in China. PLoS ONE 2013, 8, e68783. [CrossRef] [PubMed]

40. Glenn, F.; Daynard, T. Effects of genotype, planting pattern, and plant density on plant-to-plant variability and grain yield of corn. Can. J. Plant Sci. 1974, 54, 323-330. [CrossRef]

41. Pan, X.; Wang, G.; Chen, J.; Wei, X. Elevated growth redundancy and size inequality in spring wheat populations mulched with clear plastic film. J. Agric. Sci. 2003, 140, 193-204. [CrossRef]

42. Jessop, R.S.; Stewart, L.W. Effects of crop residues, soil type and temperature on emergence and early growth of wheat. Plant Soil 1983, 74, 101-109. [CrossRef]

43. Cochran, V.L.; Elliott, L.F.; Papendick, R.I. Effect of Crop Residue Management and Tillage on Water Use Efficiency and Yield of Winter Wheat 1. Agron. J. 1982, 74, 929-932. [CrossRef]

44. Su-Juan, L.I.; Ji-Kang, C.H.; Fu, C.; Lin, L.I.; Zhang, H.L. Characteristics of growth and development of winter wheat under zero tillage in North China Plain. Acta Agron. Sin. 2008, 34, 290-296.

45. Fanlei, K.; Jichao, Y.; Hailin, Z. Effect of tillage practice on growth and development and yield of winter wheat in double cropping area in North China. Acta Agron. Sin. 2013, 39, 1612-1618.

46. Olsen, J.M.; Griepentrog, H.W.; Nielsen, J.; Weiner, J. How Important are Crop Spatial Pattern and Density for Weed Suppression by Spring Wheat? Weed Sci. 2012, 60, 501-509. [CrossRef]

47. Hol, W.H.G.; Boer, W.D.; Hooven, F.T.; Putten, W.H.V.D. Competition Increases Sensitivity of Wheat (Triticum aestivum) to Biotic Plant-Soil Feedback. PLoS ONE 2013, 8, e66085. [CrossRef] [PubMed]

(C) 2018 by the authors. Licensee MDPI, Basel, Switzerland. This article is an open access article distributed under the terms and conditions of the Creative Commons Attribution (CC BY) license (http:/ / creativecommons.org/licenses/by/4.0/). 